\title{
Effect of aminoacids on the fungicidal activity of quaternary ammonium salts
}

\author{
JERZY PIĄTKOWSKI and MICHAE ŚWIĄTEK
}

Institute of Genetics and Microbiology, University of Wrocław Przybyszewskiego 66/73, PL-51-148 Wrocław, jurekp@microb.uni.wroc.pl

Piątkowski J., Świątek M.: Effect of aminoacids on the fungicidal activity of quaternary ammonium salts. Acta Mycol. 45 (2): 207-217, 2010.

Amphipatic compounds exhibit an antimicrobial action both on bacteria and fungi. It is caused by a penetrative property of hydrophobic carbon chain of the compuound into a plasma membrane as well as by additional interaction of membrane elements and a hydrophilic amphipathic compound head. Bactericidal and fungicidal activity of this compound strongly depends on chemical environmental factors. In general, microorganisms are not as sensitive in a full medium as in a minimal one and the level of sensitivity rises when the amphipatic compounds are presend in destilled water. Similarly, the sensitivity is stronger in fluid than on solid medium. Our researches revealed however that some aminoacids, although they are complex organic compounds, increase the microbial sensitivity to some tested compound. This efect depends on a microorganism and on a kind of compound. The highest hipersensitivity has been observed against yeast-like fungi when arginine was a cooperating aminoacid. The effect concerns Trichosporon but not E.coli, not occurs in relation to SDS, quaternary ammonium salt IA, and bisammonium salts. Certainly the effect exhibit QAS, which have simple composition of hydrophilic „,head” consisting only of methyl group, attaching to alkilic chain possessing keton group, build of 14 or 16 carbon atoms.

Key words: amphipathic compound, quaternary ammonium salts, yeast, Trichosporon

\section{INTRODUCTION}

Quaternary ammonium salts (QAS) are ammonium ion $\mathrm{NH}_{4}^{+}$derivatives, in which all the four hydrogen atoms have been replaced with organic substituents. As the nitrogen atoms are negative, the ammonium group is hydrophilic. If one of the substituents is a hydrophobic alkyl chain, it confers the molecule an amphiphilic character.

QAS are found in living organisms where they perform physiological functions. Trimethyllysine, which is involved in the mitogenesis of human limphocites 
(Suba et al. 1980), has been detected in proteins, confering them specific features (Houtz et al. 1989). Carnitine enables transport of fatty acids through the inner mitochondrial membrane (Stryer 1999). Betaino-glycine is utilized by bacteria, algae, higher plants and animals for osmoregulation (Weretilnyk et al. 1989). Homarine acts in crustacea as a donor of methyl group (Netheron, Gurin 1982).

There are also QAS that have long been known for their toxic activity. Charamine, a derivative of aliphatic amino acids, is an antibiotic produced by some algae. Fascaplysin, a derivative of indol, is a red pigment toxic to microorganisms (Roll et al. 1988), obtained from a marine sponge. The heterocyclic compound bromogramine inhibits mitosis (Sato, Fenical 1983).

The basic mechanism responsible for the toxic effect of amphiphilic compounds depends on their affinity for cell membranes. At a high QAS concentration, pores filled with water may occur in the plasma membrane. The walls of the pores are composed of hydrophilic heads of QAS (Kuczera 1983). The salts may also bind to a specific site of the plasma membrane protein, thus changing its conformation (Helenius, Simons 1975). In this way, the activity of the plasma membrane enzymes has been inhibited (Samuel 1972; Baltscheffsky H., Baltscheffsky M. 1974). Enzymatic activity will also be inhibited when a lipid supporting the activity of the enzyme has been washed away by the QAS (Coleman, Allison 1973).

The mechanism governing the action of QAS on fungi depends on the composition of the compounds. It has been found that QAS act at the plasma membrane level (Kołodyński et al. 1984; Skała et al. 1988; Piątkowski et al. 1990; Lachowicz, Piątkowski 1995) and at the level of intracellular structures - mitochondria or lisosomes (Hussain et al. 1987). An important factor influencing the yeast cell sensitivity to QAS is the cell genotype (Obłąk et al. 1988; Piątkowski et al. 1990; Lachowicz et al.1992).

In the study reported on in this paper, the effect of enhanced QAS toxicity against yeast and Trichosporon cutaneum in the presence of some aminoacids was examined. Especially arginine was found to be powerful in enhancing the effect of tetradecacarbonylmethyloxy-N,N-trimethylammnium chloride on the fungi. This effect was also observed with a similarly constructed QAS, which differed only in the length of the alkyl chain.

\section{MATERIALS AND METHODS}

The QAS being studied were obtained from the Department of Chemistry, Wrocław University of Technology, by Prof. Stanisław Witek.

The prototrophic yeast strain Saccharomyces cerevisiae SM5 came from the Institute of Microbiology, University of Wrocław; Trichosporon cutaneum UCD 54169 from the Institute of Biophysics and Biochemistry Polish Academy of Sciences, Warsaw; Escherichia coli PCM 2057, Pseudomonas aeruginosa PCM 2058 and Staphylococcus aureus PCM 2054 from the Institute of Immunology and Experimental Therapy Polish Academy of Sciences, Wrocław. 
Table 1

Compounds used in investigations

\begin{tabular}{|c|c|}
\hline Compound & Chemical formula \\
\hline $\begin{array}{l}\text { N-dodecyl-N, N-dimethyl-N-[3-( } \beta \text {-methylo- } \beta \text { - } \\
\text { nitrovinyl)- } 6 \text {-methoxybenzyl] ammonium } \\
\text { chloride ( IA ) } \\
* \text { Mw } 466\end{array}$ & $\underbrace{}_{\mathrm{NO}_{2}\left(\mathrm{CH}_{3}\right) \mathrm{C}=\mathrm{CH}} \mathrm{CH}_{\substack{\left.\mathrm{C}_{12} \mathrm{H}_{25} \\
\mathrm{CH}_{2}-\mathrm{Cl}^{-}\right]}}^{\mathrm{N}^{+}\left(\mathrm{CH}_{3}\right)_{2}}$ \\
\hline $\begin{array}{l}\text { hexadecacarbonylmethyloxy-N, } \\
\text { N-trimethylammonium chloride } \\
* \text { Mw } 377.5\end{array}$ & $\mathrm{C}_{16} \mathrm{H}_{33}-\mathrm{COCH}_{2} \mathrm{O}-\mathrm{N}^{+}\left(\mathrm{CH}_{3}\right)_{3} \quad\left[\mathrm{Cl}^{-}\right]$ \\
\hline $\begin{array}{l}\text { tetradecacarbonylmethoxy-N, } \\
\text { N-trimethylammonium chloride } \\
* \text { Mw } 349.5\end{array}$ & $\mathrm{C}_{14} \mathrm{H}_{29}-\mathrm{COCH}_{2} \mathrm{O}-\mathrm{N}^{+}\left(\mathrm{CH}_{3}\right)_{3} \quad\left[\mathrm{Cl}^{-}\right]$ \\
\hline $\begin{array}{l}\text { decacarbonylomethyloxy-N, } \\
\text { N-trimethylammonium chloride } \\
* \text { Mw } 293.5\end{array}$ & $\mathrm{C}_{10} \mathrm{H}_{21}-\mathrm{COCH}_{2} \mathrm{O}-\mathrm{N}^{+}\left(\mathrm{CH}_{3}\right)_{3} \quad\left[\mathrm{Cl}^{-}\right]$ \\
\hline $\begin{array}{l}\text { sodium dodecyl sulphate (SDS) } \\
{ }^{*} \text { Mw } 288.4\end{array}$ & $\mathrm{H}_{3} \mathrm{C}-\left(\mathrm{CH}_{2}\right)_{10}-\mathrm{CH}_{2} \mathrm{OSO}_{3}^{-} \quad\left[\mathrm{Na}^{+}\right]$ \\
\hline $\begin{array}{l}\text { decacarbonylmethyloxy-N, } \\
\text { N-trimethylbisammonium chloride }\left(\mathrm{C}_{10} \text { bis }\right) \\
* * \text { Mw } 585.0\end{array}$ & 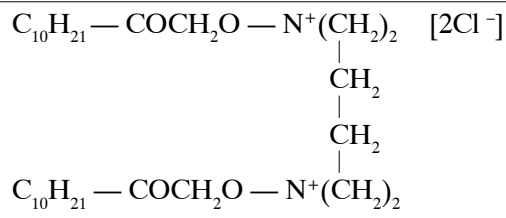 \\
\hline
\end{tabular}

Explanations: ${ }^{*}$ monoammonium salts, ${ }^{* *}$ bisammonium salts, $\mathrm{Mw}-$ molecular weight.

All the strains were stored at minus $70^{\circ} \mathrm{C}$ in the appropriate glycerol medium. They were precultivated for 24 hours in liquid full medium: Yeast and Trichosporon in YPG (glucose 2\%, Yeast extract 1\%, Bacto Peptone 1\%), bacteria in Nutrient Broth.

After translocation of $10 \mu \mathrm{l}$ of the preculture to $10 \mathrm{ml}$ of such medium, the microorganisms were incubated until the logarithmic phase of growth was attained.

In order to estimate the QAS concentrations at which $100 \%$ of cells is killed or their growth inhibited, the cells were washed twice by centrifugation in physiological liquid $(0.9 \% \mathrm{NaCl})$ and then placed with an inoculating loop on the medium suplemented with the QAS being tested. The compounds concentrations were: 5, 10, 20, $40,80,160,320$, and $640 \mu \mathrm{M}$. The medium used for yeast-like organisms was YPG or minimal synthetic medium YNB; for bacteria - nutrient broth or minimal Davies medium $\left(\mathrm{K}_{2} \mathrm{HPO}_{4}, 0.7 \%\right.$; $\mathrm{KH}_{2} \mathrm{PO}_{4}, 0.2 \%$; sodium citrate, $0.05 \%$; $\left(\mathrm{NH}_{4}\right)_{2} \mathrm{SO}_{4,} 0.1 \%$; $\mathrm{MgSO}_{4} \times 7 \mathrm{H}_{2} \mathrm{O}, 0.01 \%$; glucose, $1 \%$ ). YNB medium and Davies medium were supplemented, if necessary, with $3 \%$ of Casamino Acids or aminoacids at a concentration of $40 \mu \mathrm{g} / \mathrm{ml}$. After 24 hours of fungus- or 12 hours of bacteria incubation the growth of these microorganisms was detected to assign the compound concentration at which the growth of $100 \%$ of the cells were inhibited. In the case of the liquid media, the cells after a compound treatment were spreaded onto full agar medium to verify their viability.

Before the cells were planted onto the media with the inoculated loop, they were dispersed in physiological liquid to the optical density of 0.05 measured by 
spectrophotometry at $550 \mathrm{~nm}$. The solid media on which the microorganisms were cultivated had the form of a slant in a test-tube. The activity of the compounds in the liquid medium was verified by pouring the cells of Trichosporon into $10 \mathrm{ml}$ of YNB and YNB with amino acids, at the concentration of $10^{4} \mathrm{cells} / \mathrm{ml}$. After $30 \mathrm{~min}$. of incubation at $28^{\circ} \mathrm{C}, 10 \mu \mathrm{l}$ samples of the cell suspension were collected and placed on the full solid medium in order to estimate viability.

Since the distance between the compound concentration used was long (the next one was twice as high as the former one), the results obtained were in high degree repeated. That's why no variation values has been marked in the figures.

\section{RESULTS}

In order to verify to what extent the sensitivity of Trichosporon cutaneum depends on the medium composition, the cells were placed in three types of the growth medium (described in the section „Materials and methods”): YPG, YNB with glucose as the only carbon source, and YNB with glucose and Casamino Acids as the source of amino acids. In each type of medium different concentrations of QAS were used. The viability of the cells was evaluated after incubation for 3 days at $28^{\circ} \mathrm{C}$.

The results are gathered in Figure 1. As shown by this data, the cells on YPG and YNB + Casamino Acids were viable when the concentration of the C14 compound was lower than $40 \mu \mathrm{M}$. On the other hand, growth on the medium without amino acids was visible even at the $\mathrm{C} 14$ concentration of $160 \mu \mathrm{M}$. This implies that the

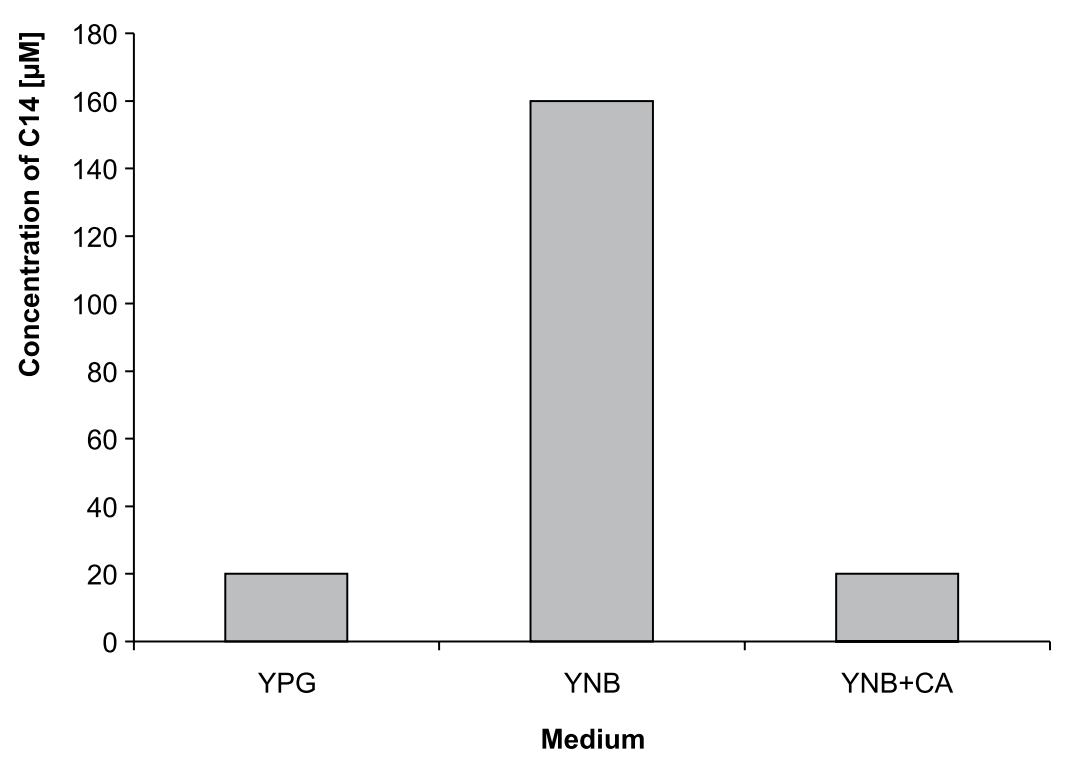

Fig. 1. Growth of T.cutaneum on the medium YPG,YNB and YNB+Casamino acids at the presence of $\mathrm{C} 14$ salt. 
sensitivity of the strain T. cutaneum to C14 in the absence of amino acids is approximately four times as high as when they are present in the medium.

Taking into account the considerable difference in sensitivity, we decided that the method is sensitive enough to futher investigations.

Upon analysis of the results, a number of detailed guestions arise: Is the effect of supersensitivity in the presence of aminoacids characteristic for all amphiphilic compounds, or only for a narrow group of molecules similar to one another? It is only the $\mathrm{C} 14$ salt that produces such an effect? To answer thise questions, some other compounds were tested for their activity against T. cutaneum. Two of them differed from $\mathrm{C} 14$ only in that they had a $\mathrm{C} 10$ and $\mathrm{C} 16$ carbon atoms in alkil chain respectively. The third and fourth was bisammonium compounds: one - C10, the other - C16. The fifth salt, so colled IA, differed in the hydrophilic „head” composition. The last one of the compounds tested was SDS, which is not an ammonium salt and, in contrast to the other mentioned, occurs in water as an anion.

The results of the tests with all the compounds mentioned are presented in Figure 2 .

As shown by the results, (Fig. 2) apart from C14 this is the C16 monoammonium salt alone that produces the effect of amin oacid-dependent hipersensitivity, although the effect is poorer than the one developed by $\mathrm{C} 14$. Possesing 10 carbon atoms C10 QAS was equally active both in the YNB and the YNB+A medium, where the growth of $T$. cutaneum became visible when the compound concentration did not exeed $320 \mu \mathrm{M}$. Hipersensitivity was not observed with IA QAS and SDS.

A question was whether or not the influence of amino acids on the sensitivity of the microorganisms was specyfic for T. cutaneum? Another yeast-like organism, Saccharomyces cerevisiae, was chosen to carry out tests that would help to answer this

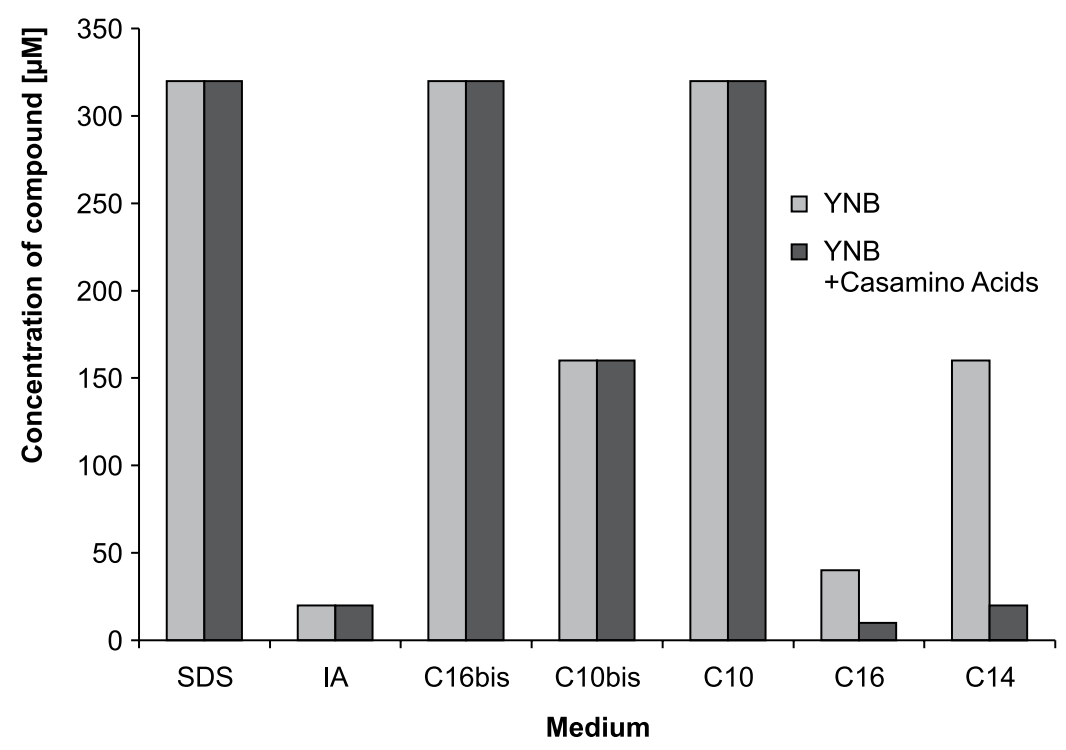

Fig. 2. Growth of T.cutaneum on YNB and YNB+CA at the presence of amphifilic compounds. 


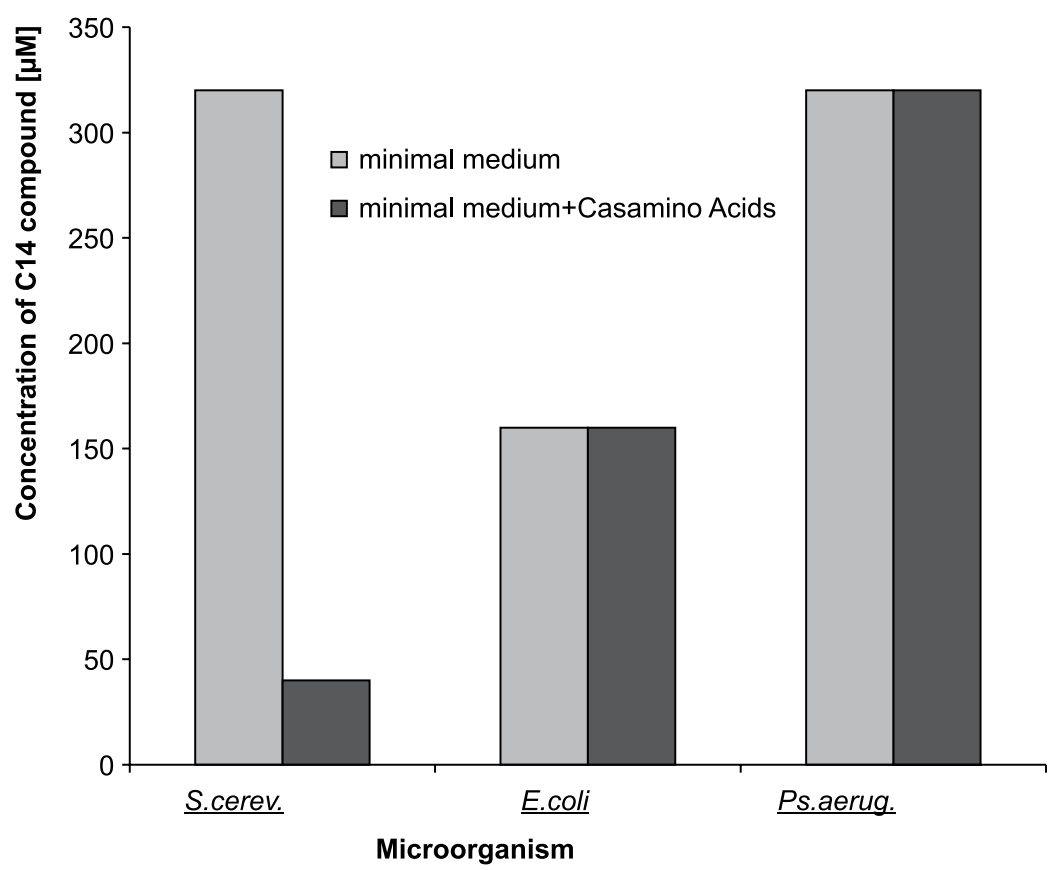

Fig. 3. Effect of supersensitivity of E.coli, Paeruginosa, S.cerevisiae and to C14 compound.

question. Two species of bacteria were also investigated for sensitivity - Echerichia coli and Pseudomonas aeruginosa. As it can be infered from the results in Figure 3, hypersensivity is observed with $S$. cerevisiae but not with the bacteria used.

If the effect is stimulated by the medium Casamino Acids, it is obviously interesting to detect what kind of amino acids increases the sensitivity to those QAS. In order to verify this, the next experiment did not involve Casamino Acid medium; use was made of particular amino acids present in the YNB medium. One different amino acid at concentration in the medium $40 \mu \mathrm{g} / \mathrm{ml}$ was present in each variant of the media.

As shown by the data in the Tabele 2 shows, each of the amino acids being studied affected the sensitivity of T. cutaneum to a different extent. The greatest growth inhibition was observed, when YNB was supplemented with arginine. To a slighty smaller degree than by arginine was the antifungal activity of the QAS enhanced by uracyl, tryptophan, cysteine and leucine. Significantly lower inhibition occured from thyrosine, lysine. Only a slight inhibiting efect was produced by treonine and glutamic acid. No increase in sensitivity was found in the presence of adenine, histidine or proline.

The experiments involving solid media did not provide information as to whether the QAS had a toxic or only an inhibitory effect on fungal growth. If this had been an inhibitory effect without cell destruction, restoration of growth should have been detected when the cells were separated from the C14 (after previous treatment with this salt), and brought into a fresh medium free from $\mathrm{C} 14$. We used a liquid medium where Trichosporon cells were incubated in the presence of C14 and thereafter 
Table 2

Growth of T. cutaneum on YNB suplemented with C14 and an aminoacid

\begin{tabular}{|c|ccccccc|}
\hline \multirow{2}{*}{ Aminoacid } & \multicolumn{7}{|c|}{ Concentration of the C14 compound $[\mu \mathrm{g} / \mathrm{ml}]$} \\
& & 0 & 20 & 40 & 80 & 160 & 320 \\
& & & & & & \\
\hline Leu & + & + & + & - & - & - \\
\hline Pro & & + & + & + & + & + & + \\
\hline His & + & + & + & + & + & + \\
\hline Lys & + & + & + & + & - & - \\
\hline Arg & + & + & - & - & - & - \\
\hline Cys & + & + & + & - & - & - \\
\hline Glut & + & + & + & + & + & - \\
\hline Met & + & + & + & - & - & - \\
\hline Ala & + & + & + & - & - & - \\
\hline Thr & + & + & + & + & + & - \\
\hline Ade & + & + & + & + & + & + \\
\hline Tyr & + & + & + & + & - & - \\
\hline Trp & + & + & + & - & - & - \\
\hline Ura & + & + & + & - & - & - \\
\hline Glyc & + & + & + & + & - & - & - \\
\hline
\end{tabular}

placed on the YPG solid medium which was free from C14, in order to assess how many cells had survived. The results of the experiment indicate that when the cells were incubated with $\mathrm{C} 14$ in the YNB liquid medium, the critical compound concentration which killed them amounted to $5 \mu \mathrm{M}$. When they were grown in YNB with amino acids, the killing concentration was $0.55 \mu \mathrm{M}$ (Fig. 4).

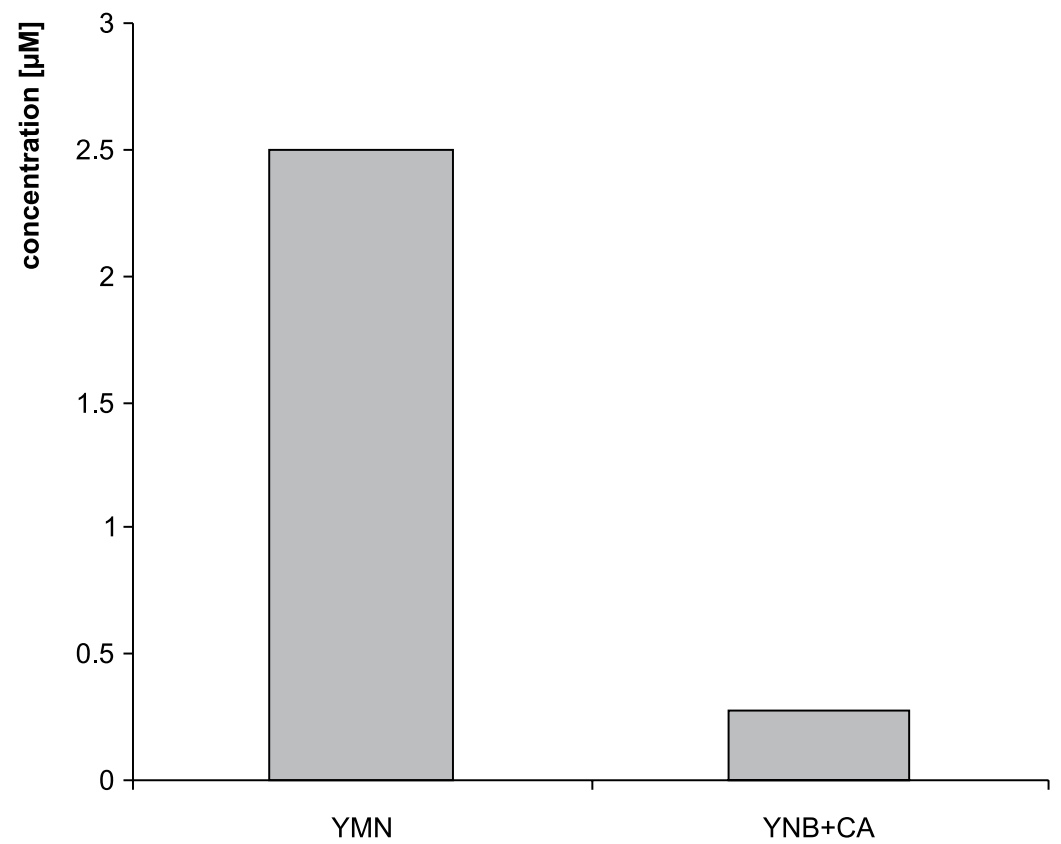

Fig. 4. Viability of Trichosporon cutaneum cells in the presence of C14 compound and aminoacids.

YNB - a medium without aminoacids; YNB + CA - a medium with aminoacids 
The sensitivity of Trichosporon was tested using two media: YNB and YNB supplemented with amino acids in form of Casamino Acids (YNB+CA). Figure 5 and 6 show the results of the test, in which the cells were inoculated on YNB and YNB+CA slants in such a number that made the growing colony a countable one. As shown by the photographs, the growth of the cells was more sensitive when amino acids were present in the medium. It is interesting to note that when the $\mathrm{C} 14$ concentration was lower than the inhibiting one, colony growth was enhanced to a greater extend in the presence than in the absence of Casamino Acids for the same QAS concentrations. However, with $\mathrm{C} 14$ concentration of $20 \mu \mathrm{M}$ and higher, Casamino Acid stopped supporting microbial growth and started inhibitig it.

\section{DISCUSION}

Quaternary ammonium compounds are widely used as remedies for killing microorganisms. Their inhibitory activity against bacteria (Jaszczuk, Krzywicka 1975; Zabłocki et al. 1970), fungi (Witek et al. 1978), algae (Rucka et al. 1983) and, also, agaist insects (Fulde 1976) have long be known. Desinfectant preparations applied in hospitals are available on the market (Kędzia 1981).

However, QAS are not normaly used as drugs for direct contact with a human body. In such cases, a variety of antibiotics has been applied, but their mechanism of action is not based on amphiphilic properties. The results of the research reported on in this paper shows clearly that the action of a quaternary monoammonium salt with 14 carbon atoms in the alkyl chain on Trichosporon cutaneum can be increased approximately fourfold if the environment includes amino acids. Our tests with the liquid medium substantiate not only an inhibitory but also a killing mechanism that governs the action of the compound. The toxic effect is much stronger in a liquid than on a solid medium.

The increase in sensitivity due to the interaction with amino acids does not occur in all organisms. There in no doubt that it would be interesting to carry out such tests with a greater number of different living cells. The problem is important and worth studying, so will be subject to further experiments reported in a separate paper in the future. The purpose of our study reported on in this paper was to provide the widest possible background to a comprehensive analysis of the effect of „cooperation” between amino acids and QAS. The effect occurs in Trichosporon but not E. coli or probably other gram negative rods of bacteria.

Effect of supersensitivity induced by the presence of amino acids not occurs does not occur when the Trichosporon strain is treated with SDS, quaternary ammonium salt IA or bisammonium salts. At the present stage of our investigation it is difficult to decide which element in the structure of the compounds is essential in this context. The effect is certainly associated with those QAS that have simple composition of hydrophilic „head” where there is only a methyl group attached to alkylic chain possesing a keton group build of 14 or 16 carbon atoms. It is still unknown whether or not an alkilic chain without the keton group would develop such an effect. Further tests are needed to define the exact structural requirements triggering this effect. 


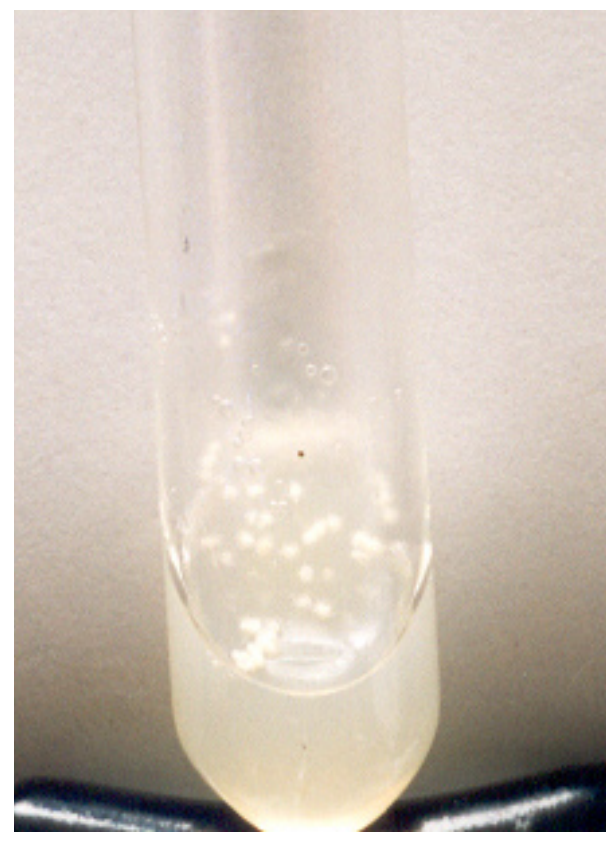

$40 \mu \mathrm{M}$

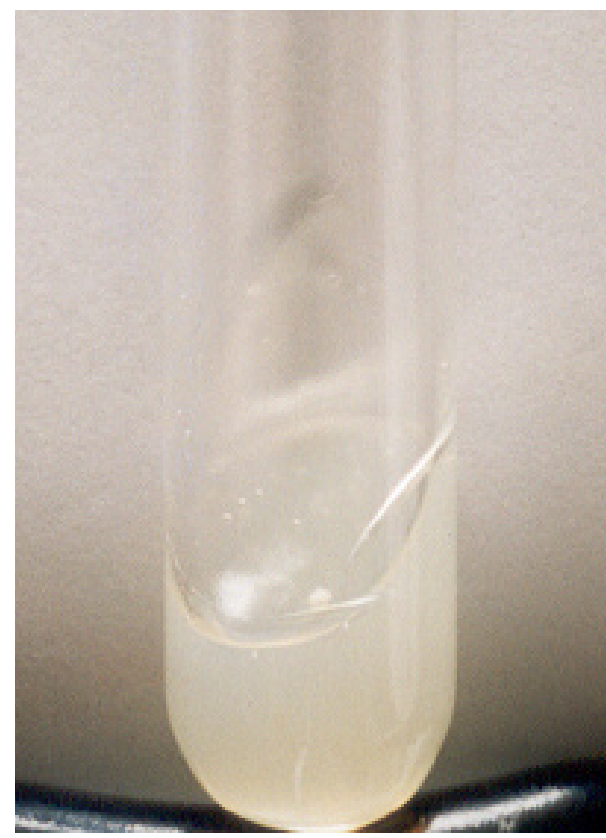

$160 \mu \mathrm{M}$

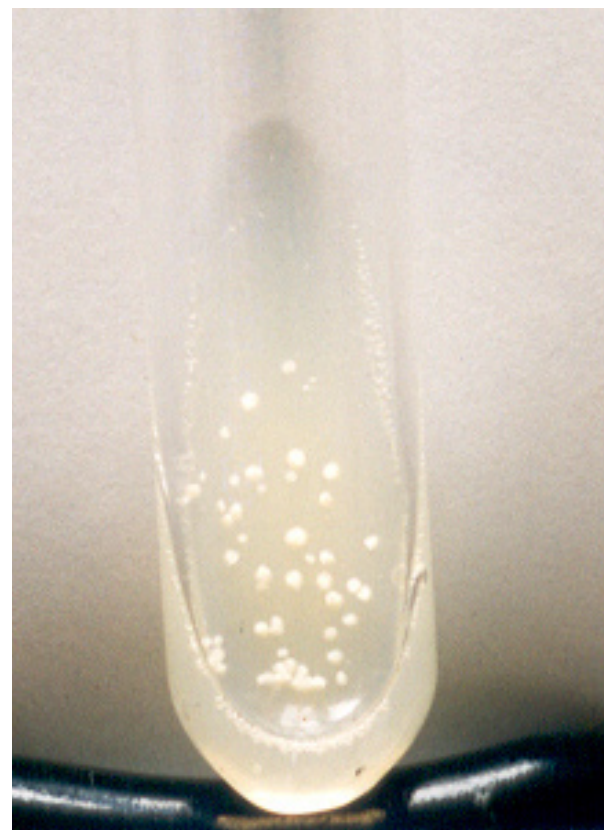

$80 \mu \mathrm{M}$

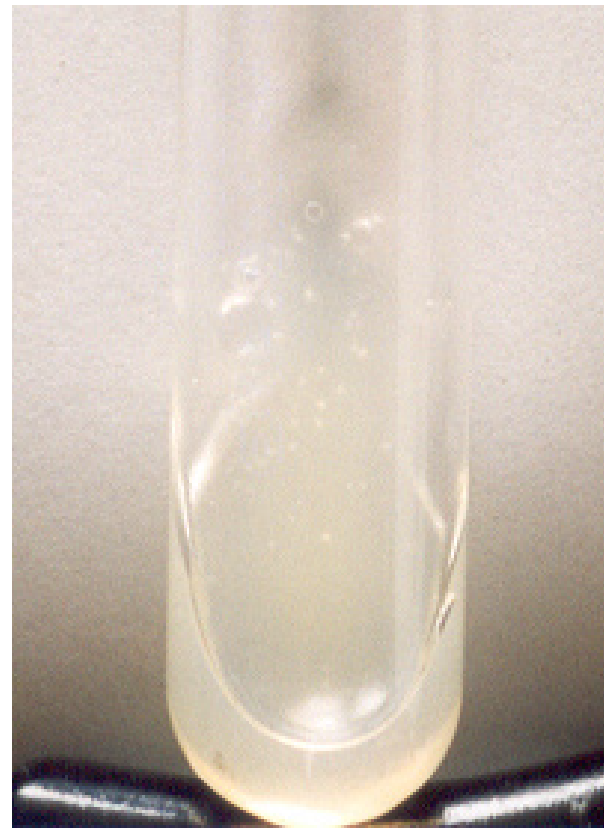

$320 \mu \mathrm{M}$

Fig. 5. Growth of Trichosporon cutaneum on the medium YNB at the presence of C14 compound. 


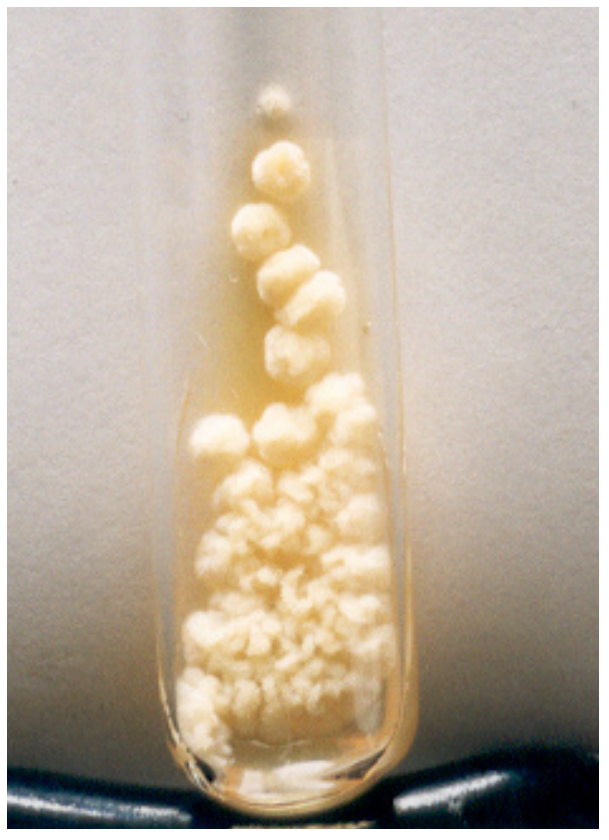

$5 \mu \mathrm{M}$

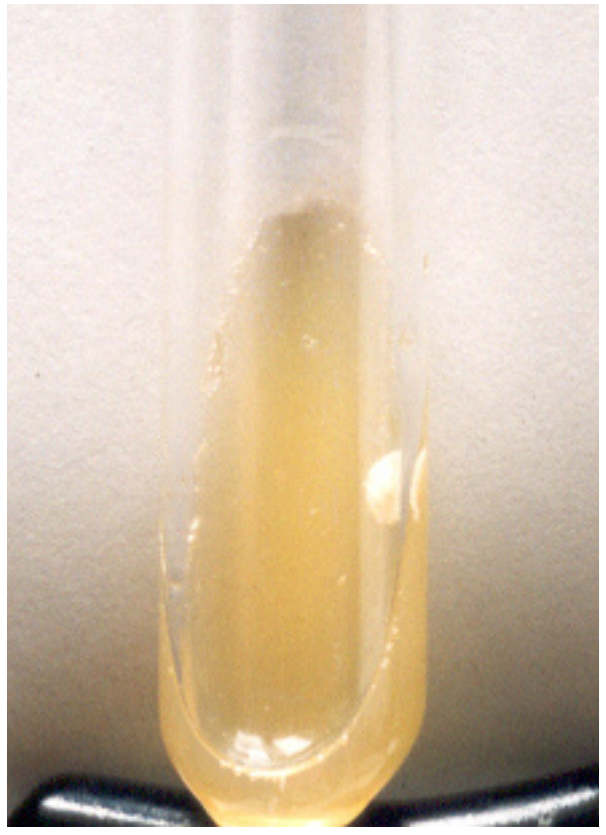

$20 \mu \mathrm{M}$

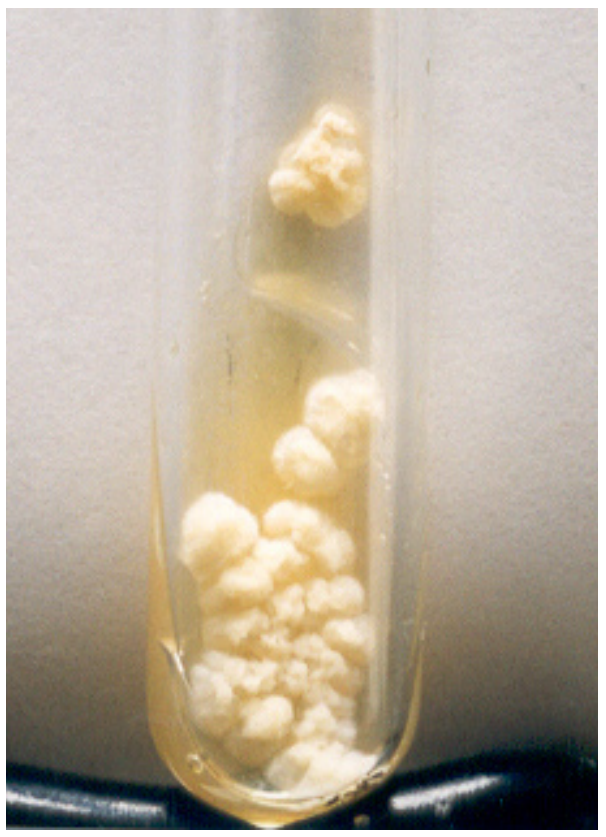

$10 \mu \mathrm{M}$

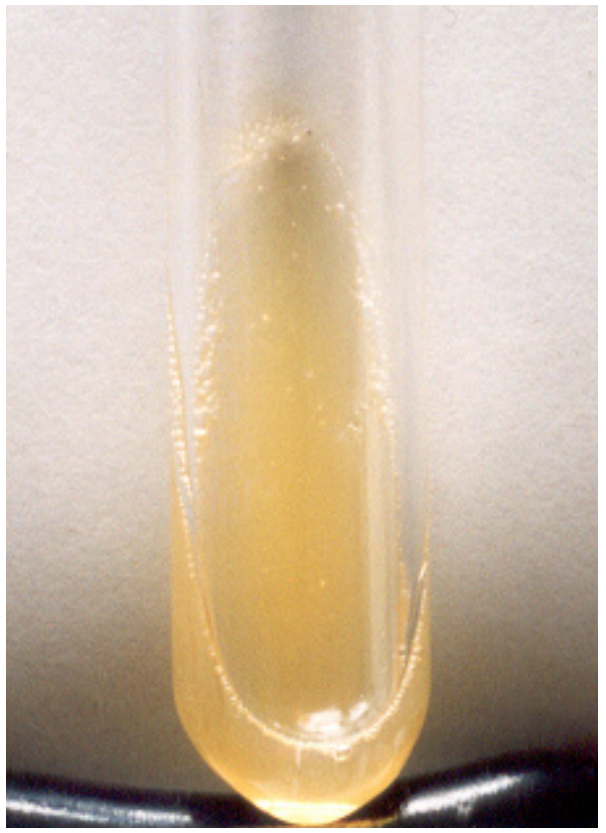

$40 \mu \mathrm{M}$

Fig. 6. Growth of Trichosporon cutaneum on the medium YNB at the presence of C14 compound and amino acids. 
The results obtained so far indicate that the stimulation of the fungicidal activity of amfphifilic compounds by amino acids is not a common feature of the QAS, it probably pertains to only a narrow group of them.

The research on particular amino acids revealed an important role of arginine in increasing the sensitivity of yest-like organisms to $\mathrm{C} 14$. As far as the nutrients being tested are concerned, this rise in sensitivity does not seem to be caused by compounds having a cyclic composition, e.g., proline, histydyne or adenine. On the basis of the results obtained up till now it is difficult to explain the mechanism of cooperation between aminoacids and C14. What should further investigations concern on? Maybe it is necessary to verify whether or not the interaction of amino acids with the amino acid transport system through the plasma membrane activates the carriers transporting C14 towards a cell? Mayby the association of arginine to permease changes the conformation of the protein in such a way that it becames more sensitive to inhibition by C14. It is well known that amphiphilic compounds which act on proteins at appropriately low concentrations may specifically bind to some sites of this protein. If the protein changes its conformation, the enzymatic activity may become inhibited. The chemical composition of both arginine and C14suggest that they are likely to fuse and that arginine transported by permease into the cells might enable co-transport of C14.

Summing up, with the results obtained it is possible to characterise the interesting phenomenon of amino acids induced increase in the fungicidal activity of the QAS. This effect is interesting for cognitive reasons, as it may contribute to a better understanding of the mechanism governing the action of quaternary ammonium compounds on microorganisms. Of equal importance seem to be the therapeutic aspect of this phenomenon. Our results indicate that the observed supersensitivity is detected in yeast-like organisms, not in gram negative bacteria. If further researches revealed that also epithelial cells are resistant to this effect, this would means that the aminoacid-C14 combination is a remedy against Trichosporon, which is believed to be a pathogenic microorganism colonising espetially throat. On the other hand, some gram negative bacteria, such as Moraksella catharalis, play an important role in upper respiratory tracts. So it should be advantageous to have a drug which kills microorganisms such as Trichosporon and leaves the natural and useful bacteria intact. A promising result is that $\mathrm{C} 14$ acts significantly stronger in a liquid environment.

The presented results disclosed some basic features of the observed phenomenon of the amino acid induced rise in the activity of QAS. It is obvious that the final explanation of the mechanism of cooperation between the compounds needs further experiments. 


\section{REFERENCES}

Baltscheffsky H., Baltscheffsky M. 1974. Electron transport phosphorylation. Annu. Rev. Biochem. 43: 871-897.

Coleman R., Allison A. C. 1973. Membrane-Bound Enzymes and Membrane Ultrastructure. Biochim. Biophys. Acta 300: 1-30.

Fulde S. 1976. Rozwój badań w zakresie syntezy i przygotowania produkcji enolofosforanów owadobójczych. Pestycydy 4: 1.

Helenius A., Simons K. 1975. Solubilization of Membranes by Detergents. Biochim. Biophys. Acta 415: $29-71$.

Houtz L., Stults J. T., Mulligan R. M., Tolbert N. E. 1989. Post-translational modifications in the large subunit of ribulose biphosphate carboxylase/oxygenase. Proc. Natl.Acad. Sci. U.S.A. 86: 1855-1859.

Hussain M., Leibowitz M. J., Lenard J. 1987. Killing of Saccharomyces cerevisiae by Lysosomatropic Detergent N-Dodecylimidazole. Antimicrobial Agent and Chemotherapy 512-517.

Jaszczuk E., Krzywicka H. 1973. Oporność bakterii na działanie niektórych kationowych związków powierzchniowo czynnych. Roczn. PZH 24: 241.

Kędzia W. B. 1981. Dezynfekcja w medycynie i farmacji. PWN, Warszawa.

Kołodyński J., Ułaszewski S., Grobelny D., Witkowska R., Witek S., Lachowicz T. 1984. Effect of some quaternary benzylammonium salts on physiology of yeast. Acta Microbiologica Polonica 33: 119130.

Kuczera J. 1983. Wpływ amfifilowych detergentów na błony liposomów. Zagadnienia Biofizyki Współczesnej. PWN Warszawa 53-101.

Lachowicz T. M., Piątkowski J. 1995. Quaternary ammonium salts and arginine are inhibitors of general amino acid permease in yeast. Pestic Sci. 43: 169-180.

Lachowicz T.M., Obłąk E., Piątkowski J. 1992. Auksotrophy - Stimulated Sensitivity to Quaternary Ammonium Salts and Its Relation to Active Transport in Yeast. Bulletin of Polish Academy of Sciences. Biological Scien. 40: 173-182.

Netherton J. C., Gurin S. 1982. Biosynthesis and physiological role of homarine in marine shrimp. J. Biol. Chem. 257: 971-1011.

Obłąk E., Ułaszewski S., Lachowicz T. M. 1988. Mutants of Saccharomyces cerevisiae resistant to a quaternary ammonium salt. Acta Microbiologica Polonica 37: 261-269.

Piątkowski J., Orłowska G., Lachowicz T. M. 1990. Sensitivity of aminoacid transport in Yeast to amonium salts. (In:) Genetic of respiratory enzymes in yeasts. Wrocław University Press. 103-113.

Roll D. M., Ireland C. M., Lu H. S. M., Clardy J. 1988. Fascaplysin, an unusual pigment from the marine sponge Fascaplysinopsis sp. J. Org. Chem. 53: 3276-3278.

Rucka M., Oświęcimska M., Witek S. 1983. New biocides for cooling water treatment quaternary ammonium salts derivatives of glycine esters. Environ. Protect. Enqin. 9: 25-31.

Sato A., Fenical W. 1983. Gramine-derived bromoalkaloids from the marine Bryozoans Zoobotryon verticillatum. Tetrahedr. Lett. 24: 481-484.

Samuel R. 1972. Reconstitution of biological membranes. Biochim. Biophys. Acta 265: 241-296.

Skała J., Orłowska-Matuszewska G., Misiewicz M., Oświęcimska M., Witek S., Kotylak Z. 1988. Biological effect of alkoxymethylene trimethylammonium chlorides on yeast Saccharomyces cerevisiae. Acta Microbiologica Polonica 37: 271-280.

Stryer L. 1999. Biochemia. PWN Warszawa.

Suba Z., Szende B., Lapis K., Takacs J., Elek G. 1980. ع-N-Trimethyllysine, a natural cell component with mitogenic activity. Neoplasma 27: 11-23.

Weretilnyk E. A., Bednarek S., McCue K. F., Rhodes D., Hanson A. D. 1989. Comparative bichemical and immunological studies of the glycine betaine synthesis pathway in diverse families of dictyledons. Planta 178: 342-352.

Witek S., Grobelny D., Ptaszkowska J., Bielecki A., Bakuniak E., Fulde S., Górska-Poczopko J. 1978. Belg.Patent No 864782.

Zabłocki B., Kotełko K., Szydłowski S., Gromska W., Izdebska K., Czerniawski E., Michno-Bednarek Z., Gościcka T., Sedlaczek L. 1970. Dokumentacja Polfy, Sterinol. 5:5. 
Wpływ aminokwasów na grzybobójcze działanie czwartorzędowych soli amoniowych

\section{Streszczenie}

Jednoamoniowa sól czwatorzędowa z 14 atomami węgla w łańcuchu węglowym wykazuje silniejsze działanie letalne wobec Trichosporon cutaneum na podłożu pełnym oraz podłożu opartym na hydrolizacie kazeiny niż na podłożu minimalnym. Taki efekt uzyskuje się również z solą o 16 węglach w łańcuchu. W przypadku dwuamoniowych związków tego typu, SDS oraz soli amoniowej z aromatycznym pierścieniem, wzrostu wrażliwości w obecności aminokwasów nie zaobserwowano. Poza T. cutaneum większa wrażliwość w obecności aminokwasów wystąpiła również w przypadku drożdży, lecz nie w przypadku testowanych bakterii Pseudomonas sp. i Escherichia coli. Największą aktywność grzybobójczą soli amoniowych uzyskano dla argininy. Efekt ten jest znacznie silniejszy w podłożu płynnym niż stałym. 